\title{
Aberrant Right Subclavian Artery Aneurysm: A Presentation of Two Cases
}

\author{
Ömer Özçağlayan,, Tuğba IIlkem Özçağlayan, ${ }^{1}$ Mücahit Doğru, ${ }^{1}$ Bozkurt Gülek²
}

\author{
'Department of Radiology, \\ Namık Kemal University Faculty of \\ Medicine, Tekirdağ, Turkey \\ 2Department of Radiology, \\ Health Sciences University Adana \\ Numune Training and Research \\ Hospital, Adana, Turkey \\ Submitted: 15.05.2017 \\ Accepted: 13.09 .2017 \\ Correspondence: Ömer Özçağlayan, \\ Namık Kemal Mah., Kampüs Cad., \\ No: 1, 59030 Süleymanpaşa, \\ Tekirdağ, Turkey \\ E-mail: omer.ozcaglayan@gmail.com

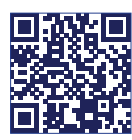 \\ Keywords: Aberrant right \\ subclavian artery; aneurysm; \\ contrast-enhanced computed \\ tomography.
}

\begin{abstract}
Aberrant right subclavian artery (ARSA) aneurysm can be an important cause of mortality or potential rupture of the esophagus or trachea. It is important to emphasize that diagnosis of ARSA aneurysm is crucial to avoid fatal complications. Contrast-enhanced computed tomography (CECT) is the best imaging modality to illustrate the necessary details of the anatomy and such complications. The aim of this report was to demonstrate the usefulness of CECT in 2 cases of ARSA aneurysm.
\end{abstract}

\section{INTRODUCTION}

An aberrant right subclavian artery (ARSA) is a rare anomaly in which the right subclavian artery stems as the last branch from the aortic arch, distal to the origin of the left subclavian artery.

The incidence of ARSA has been reported to be approximately $0.5 \%$ to $1 \%{ }^{[I]}$ The male-to-female ratio is I. Most patients with ARSA are asymptomatic at the time of diagnosis, even though the anomalous right subclavian artery may be aneurysmatic. In symptomatic patients, on the other hand, symptoms are usually secondary to impingement. The most prominent of these symptoms are dyspnea and dysphagia. Patients may also present with findings of Horner's syndrome. ${ }^{[2]}$ In $60 \%$ of patients, a Kommerell diverticulum accompanies ARSA.

An ARSA aneurysm is a very rare entity, encountered in only $3 \%$ to $8 \%$ of patients. ${ }^{[3]}$ The aneurysm has been de- fined as having a diameter between 2.5 and $5.5 \mathrm{~cm}$ (mean: $3.3 \mathrm{~cm}$ ) in the literature. ${ }^{[4]}$ The diagnosis of ARSA patients with an aneurysm is of utmost importance due to the risk of vascular rupture, in addition to the impingement effects on the trachea and the esophagus.

Presently described are 2 cases of ARSA aneurysm diagnosed coincidentally during contrast-enhanced (CE) computed tomographic (CT) examination of the chest performed for other reasons.

\section{CASE REPORT}

Case I- A 74-year-old male patient presented at the cardiology outpatient clinic with chest pain. His physical examination did not reveal any prominent features. His blood pressure was $150 / 90 \mathrm{mmHg}$. A thin-slice CECT of the thorax performed prior to a coronary angiography procedure revealed a vascular structure conforming to a 
right aberrant subclavian artery stemming from the distal aortic arch as the last branch. The vessel passed from the posterior aspect of both the trachea and the esophagus and extended toward the right upper extremity. The diameter of the ARSA was measured to be $26 \mathrm{~mm}$ at its widest section, which was con-sistent with aneurysmatic dilatation. There was also a mural thrombus, which did not cause significant narrowing of the lumen. In addition, there was dilatation corresponding to a Kommerell diverticulum in the proximal aspect of the ARSA (Figures la and $b$ ).

Case 2- A 68-year-old male patient presented at the internal medicine outpatient clinic with the complaints of abdominal pain and lethargy. The results of his physical
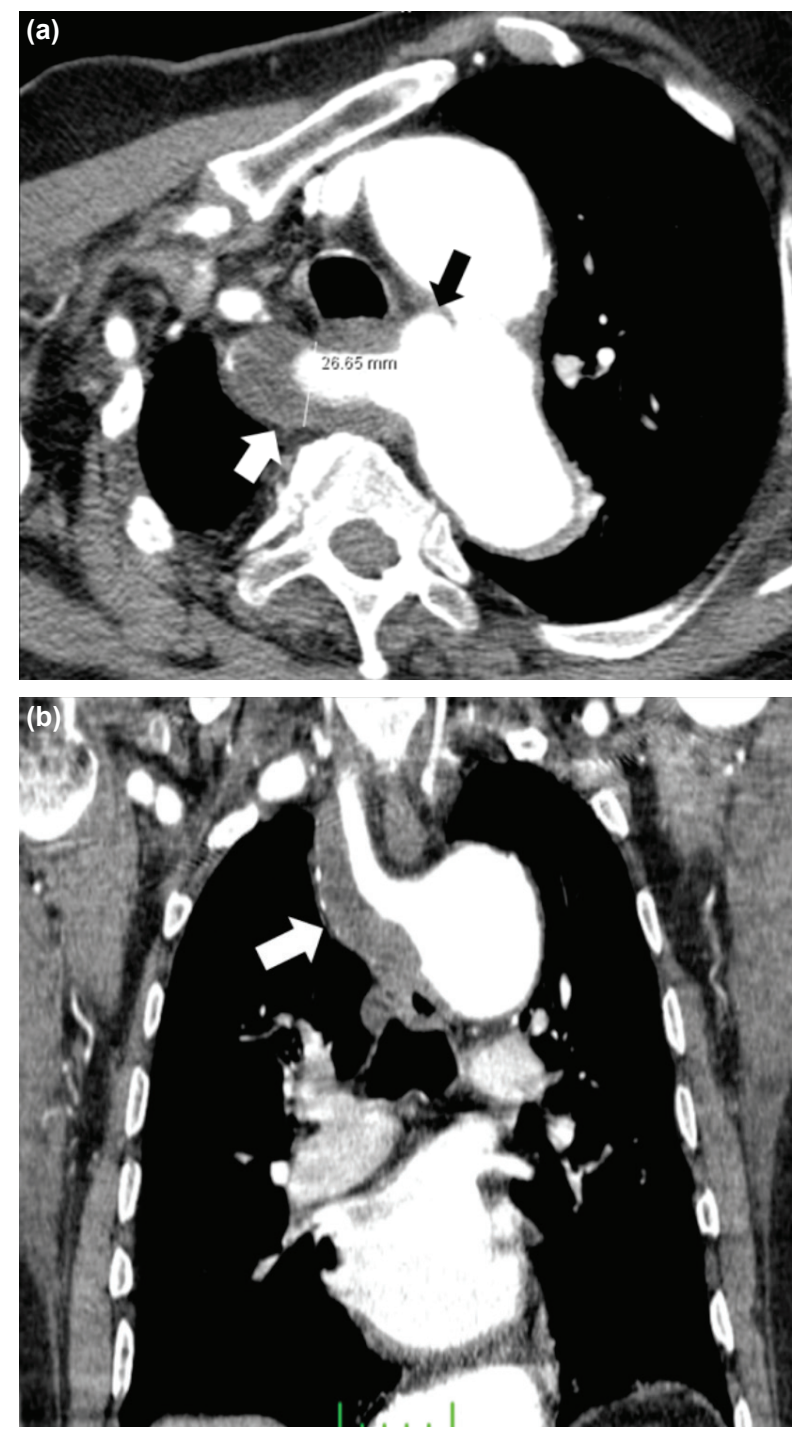

Figure 1. (a) Axial oblique contrast-enhanced computed tomography image of the first patient depicts the aberrant right subclavian artery (white arrow) associated with a Kommerell diverticulum (black arrow). The vessel calibration was increased and there was an intraluminal mural thrombus. (b) Coronal oblique reformatted contrast-enhanced computed tomography image shows the vessel's route and the mural thrombus (white arrow). examination were within normal limits. His blood pressure was $140 / 90 \mathrm{mmHg}$. Echocardiography revealed dilatation of the thoracic aorta. A CECT of the thorax was performed in order to evaluate the aorta more thoroughly. This examination disclosed an aberrant vessel stemming from the distal medial wall of the aortic arch and traversing the trachea and the esophagus from the posterior aspect before extending toward the right upper extremity. The maximum diameter of the vessel was $32 \mathrm{~mm}$, and there was a mural thrombus in the vessel, which did not cause any significant narrowing of the lumen. The findings were compatible with an ARSA aneurysm. No associated Kommerell diverticulum was present (Figures $2 \mathrm{a}$ and $\mathrm{b}$ ).
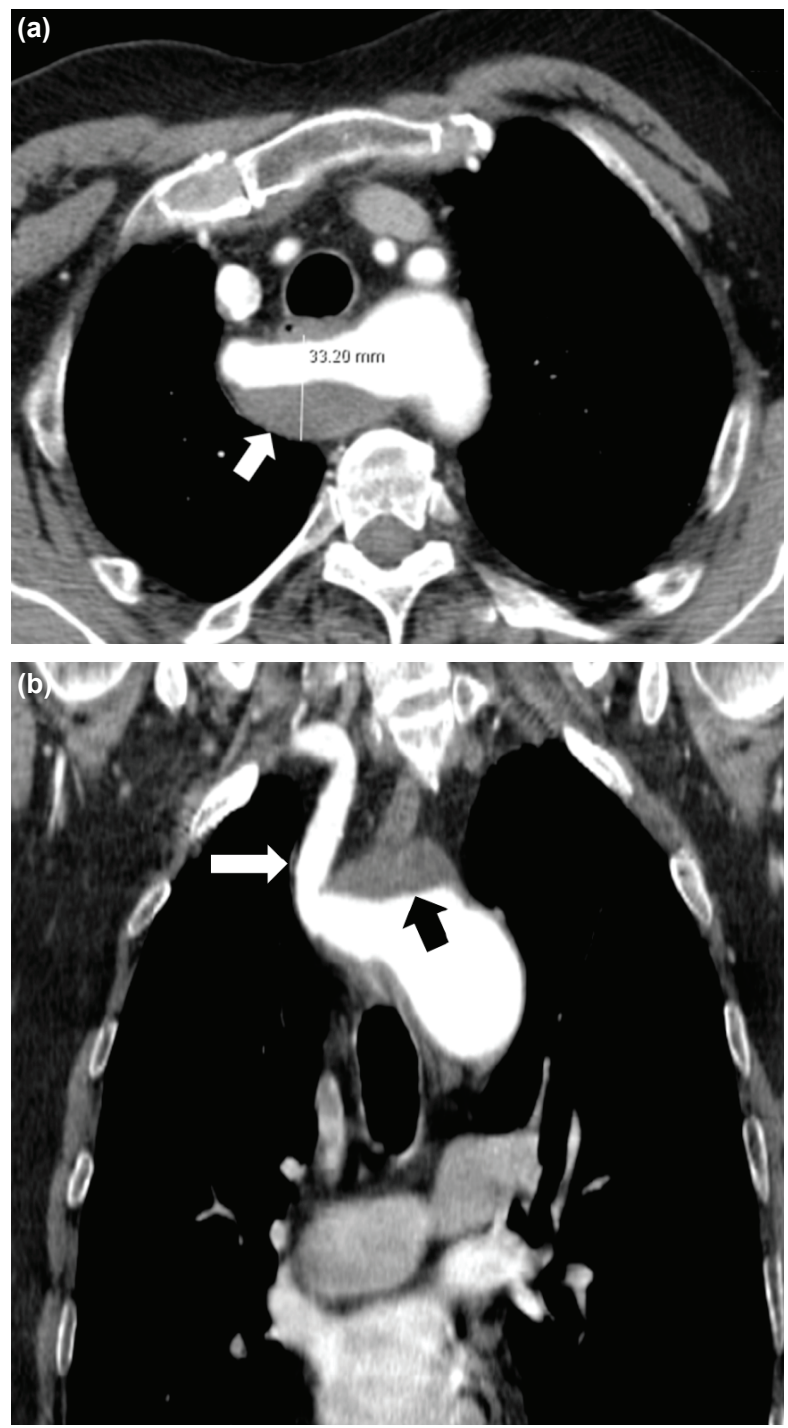

Figure 2. (a) Axial oblique contrast-enhanced computed tomography image shows the aberrant right subclavian artery of the second patient. Intraluminal thrombus (white arrow) and increased diameter are present without coexistence of Kommerell diverticulum. (b) Coronal oblique reformatted contrast-enhanced computed tomography image clearly demonstrates the route of the aberrant right subclavian artery to the right upper extremity. 


\section{DISCUSSION}

David Bayford defined a certain type of dysphagia in 1787 that he called "dysphagia lusoria," which was due to the impingement effect of an aberrant right subclavian artery on the esophagus. ${ }^{[5]}$ The first patient described by Bayford was a female patient named Jane Fordham who had become symptomatic when she was 12 years old and who died when she was 60 , due to starvation. Burckhard F. Kommerell's description of the aortic diverticulum that bears his name and which often accompanies ARSA was published in 1936. ${ }^{[6]}$

The pathophysiological mechanism of ARSA may be explained by the involution of the fourth vascular arch together with the right dorsal aorta. The seventh intersegmental artery persists in its attachment to the descending aorta, and this persistent intersegmental artery forms the aberrant right subclavian artery. ${ }^{[7]}$

The diagnosis of ARSA aneurysm has an important clinical aspect due to the risk of spontaneous rupture and esophageal perforation. ${ }^{[8]}$

Patients with an ARSA aneurysm may demonstrate an upper mediastinal widening on direct radiogram of the chest. [9] But since this is a non-specific finding, other entities must be brought to mind in the differential list, such as lymphadenopathy, substernal goiter, and enlarged aortic arch. An esophagogram may disclose the impingement effect of the ARSA aneurysm on the esophagus. ${ }^{[10]}$ Even this impingement is a non-specific event, and other sources of indentation on the esophagus may need to be researched, necessitating additional advanced diagnostic studies.

The most effective diagnostic tools in the demonstration of ARSA and associated aneurysms are catheter angiography, CECT, and plain and CE magnetic resonance (MR) angiography. ${ }^{[2]}$

The most prominent disadvantages of catheter angiography are its invasiveness and the utilization of high ionizing radiation.

Both conventional and CE MR angiography methods have an important place in the diagnostic work-up of ARSA. The major advantages of MR are that it does not use ionizing radiation and it provides first-hand multidirectional sectional imaging. But since CT has better contrast resolution and it is much more effective in the emergency setting, it is typically the modality of choice in the diagnosis of certain complications like esophageal rupture and is accepted as superior to MR in the management of emergency cases.

CECT performed with the thin-slice technique makes it possible to create multiplanar sectional post-processed imaging, and this feature enhances the contrast resolution. The short examination time and the intravenous approach of the injection of contrast media are factors that contribute to the superiority of CT.

In both of our patients, CECT of the thorax demonstrated the presence of the aneurysm perfectly, and it made it possible to evaluate the relationship between the enlarged artery and both the esophagus and the trachea very well. In addition, CECT also disclosed the presence of the Kommerell diverticulum in the first patient.

It is without doubt that CECT and CT angiography (CTA) both also have a unique place in the process of therapy planning. Especially in the emergency patient group, like those with esophageal or tracheal rupture, CT is of utmost importance in both the diagnostic and the therapeutic process, thanks to its unique speed.

In patients who are scheduled for surgery, CT provides invaluable support to the surgeon with the superior anatomical detail it provides due to its extremely high contrast resolution.

In conclusion, it must be emphasized again, that the ARSA aneurysm is a rare but clinically very important entity. As demonstrated in our 2 patients presented in this article, CTA has a very valuable role in the evaluation of emergent complications encountered in cases of ARSA due to the high quality anatomical detail it provides.

\section{Informed Consent}

Approval was obtained from the patients.

Peer-review

Internally peer-reviewed.

Authorship Contributions

Concept: Ö.Ö., T.i.Ö.; Data collection \&/or processing: Ö.Ö.; Analysis and/or interpretation: Ö.Ö., M.D.; Literature search: Ö.Ö.; Writing: Ö.Ö., B.G.; Critical review: Ö.Ö. Conflict of Interest

None declared.

\section{REFERENCES}

1. McDonald JJ, Anson BJ. Variations in the origin of arteries derived from the aortic arch, in American whites and Negroes. Am J Phys Anthropol 1940;27:91-107. [CrossRef]

2. Akman C, Soylu N, Demir T. Aberrant Right Subclavian Artery Aneurysm: Report of an Asymptomatic Patient With a Huge Aneurysm. Turkish Respiratory Journal 2005;6:39-41.

3. Davidian M, Kee ST, Kato N, Semba CP, Razavi MK, Mitchell RS, et al. Aneurysm of an aberrant right subclavian artery: treatment with PTFE covered stentgraft. J Vasc Surg 1998;28:335-9. [CrossRef]

4. Godlewski J, Widawski T, Michalak M, Kmieć Z. Aneurysm of the aberrant right subclavi-an artery - a case report. Pol J Radiol 2010;75:47-50.

5. Bayford D. An account of a singular case of obstructed deglutition. Mem Med Soc Lond 1794;2:275-86.

6. van Son JA, Konstantinov IE. Burckhard F. Kommerell and Kom- 
merell's diverticulum. Tex Heart Inst J 2002;29:109-12.

7. Amin MU, Ghafoor T. Dilated aberrant right subclavian artery (arteria lusoria), as a rare cause of dysphagia in a patient with abdominal aortic aneurysm. J Pak Med Assoc 2006;56:419-21.

8. Miller RG, Robie DK, Davis SL, Cooley DA, Klish WJ, Skolkin MD, et al. Survival after aberrant right subclavian artery-esophageal fistula: case report and literature review.J Vasc Surg 1996;24:271-5. [CrossRef]
9. Alvarez JRJ, Quiroga SJL, Nazar AB, Comendador MJM, Carro G. Aberrant right subcla-vian artery and calcified aneurysm of kommerell's diverticulum: an alternative approach. Jo-urnal of Cardiothoracic Surgery 2008;3:43. [CrossRef]

10. Rosa P, Gillespie DL, Goff JM, O'donnell SD, Starnes B. Aberrant right subclavian artery syndrome: a case of chronic cough. J Vasc Surg 2003;37:1318-21. [CrossRef]

\section{Aberran Sağ Subklavian Arter Anevrizması: İki Olgu Sunumu}

Aberran sağ subklavian arter (ASSA) anevrizması, özofagus ve trakeaya potansiyel rüptür riski nedeniyle önemli bir mortalite nedeni olabilir. Fatal komplikasyonların dışlanması açısından ASSA anevrizması tanıı koymak önemlidir. Kontrastı bilgisayarlı tomografı (BT), anatominin gösterilmesinde ve belirtilen komplikasyonları göstermesi açısından birincil görüntüleme yöntemidir. Bu yazıda, ASSA anevrizmalı iki değişik olguda kontrastlı BT'nin tanıdaki önemini göstermeye çalışıı.

Anahtar Sözcükler: Aberran sağ subklavian arter; anevrizma; kontrastlı bilgisayarlı tomografi. 